\title{
The Integration of International Capital Market from Indonesian Investors' Perspective: Do Integration Still Give Diversification Benefit
}

\author{
Sabilil Hakimi Amizuar ${ }^{1}$, Anny Ratnawati ${ }^{1,2} \&$ Trias Andati $^{1}$ \\ ${ }^{1}$ School of Business, Bogor Agricultural University, Bogor, Indonesia \\ ${ }^{2}$ Faculty of Economics and Management, Bogor Agricultural University, Bogor, Indonesia \\ Correspondence: Sabilil Hakimi Amizuar, School of Business, Bogor Agricultural University, Pajajaran Street, \\ Bogor, West Java, Indonesia. Tel: 62-821-1044-8458. E-mail: sabililhakimi@ymail.com
}

Received: June 29, 2017

Accepted: July 14, 2017

Online Published: August 25, 2017

doi:10.5539/ijef.v9n9p157

URL: https://doi.org/10.5539/ijef.v9n9p157

\begin{abstract}
The objective of this study is to analyze whether, despite the international equity liberalization and growing world financial integration, Indonesian investors can be beneficial from international diversification. The study covers both emerging markets (Indonesia, Philippines, Malaysia, Thailand, Korea, China, and Taiwan) and developed markets (USA, UK, Japan, Singapore, and Australia) over the period of January $1^{\text {st }}, 2007$ to April $30^{\text {st }}$, 2017. It uses several state-of-the-art techniques: multivariate cointegration and vector error correction models (VECM) with the analysis of impulse response function (IRF) and forecast error variance decomposition (FEVD) to analyze the long-term level of integration and time-varying correlations with the Dynamic Conditional Correlation (DCC) aproach to analyze short term level of integration. The analysis provides the evidence of integration berween Indonesian market and international markets. The findings suggest that Indonesian investors have more chance to gain international diversification benefit from developed markets rather than emerging markets as the Indonesian market has low level of integration compared to developed markets.
\end{abstract}

Keywords: developing markets, emerging markets, financial integration, indonesian investors, level of integration

\section{Introduction}

The emerge of world's economic matter which is marked by the large flow of capital in and out to certain markets, giving chance for the investor and bussinessmen in increasing profit and decreasing the risk of investment they planted. This chance is obtained by forming asset portfolio that diversified with a combination of some securities which is traded between countries. As the theory pioneered by Markowitz (1952), investor is better to do a vary portfolio into some assets having low correlation with one another so that the lower correlation between assets the higher benefit which will obtain from the portfolio. The Economic community phenomenon which makes foreign capital outflow easier from years is directly affected Indonesian capital market. That cause can be seen from how big foreign capital proportion towards total capital revolving in Indonesian capital market (IHSG) which getting bigger from year to year. Trend proportion of capital belonging in period of 2006-2016 is shown at Figure 1.

Figure 1 is shown that the larger foreign capital proportion entering domestic capital market. It can indicate that more integrated Indonesian capital market with International capital market. In fact, there is no world's capital market having perfect intergration level between countries so that the security portfolio which is diversified to some of different capital markets still giving an opportunity to get portfolio benefit. The potential benefit that will be got by international diversification motivates stock markets in some countries to identify their integration level. For instance Fan et al. (2009) invests integration level of China's stock market with International stock market which consist of America and England, it is concluded that in a short term, the effect from market integration is pretty great in boom regime condition and weak in depression regime condition. 


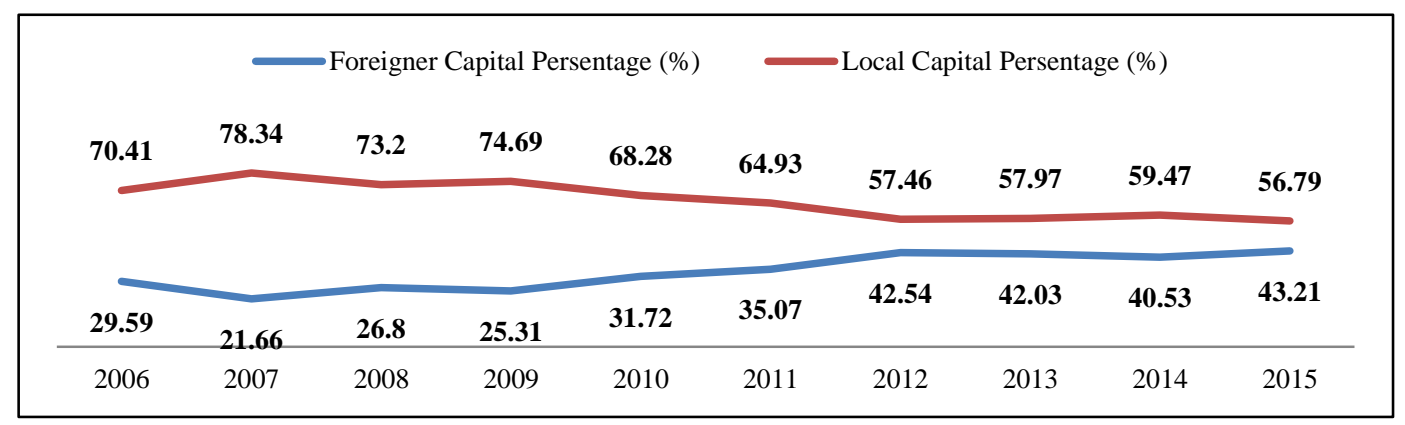

Figure 1. Trend proportion of capital belonging in period of 2006-2016

1

The integration of capital market between countries caused increase or decrease of return level and the risk in the integrated countries will be moved on both sides. This matter can give a positive or negative effect. The positive effects are creates capital market more efficient, prompt a trade cooperation system which will beneficial on both sides, and financial market development. While the negative effect for investor by increasing integration level of capital market between countries is they can limit the opportunity to get the benefit from arbitrage pricing so that the portfolio will be useless. After that the contagion effect cannot be avoided if shock in capital market of a country happened because of the same volatility trend between capital markets.

Several studies on capital market integration have been done but have different findings, the object used is also different depending on from which approach is taken. Dunis and Shannon (2005) measured the integration level between US capital markets and emerging market countries in ASEAN and Central Asia through modern portfolio theory approaches that the degree of integration investigated still provides benefits for US investors if they want to portfolio assets with those emerging market countries. Another study with the same approach but different object has been done by Jiang et al. (2013) who wants to prove whether Chinese investors who will diversify their capital into international markets still give them benefit and reduce risk, the finding is that Chinese investors get effective benefit from risk reduction when doing a stock diversification into developing countries in the Euro-American.

The current study will measure the level of integration of Indonesian capital market compared to emerging market countries comprising China, Taiwan, Korea, Malaysia, Thailand, and the Philippines and with the United States, Australia, Singapore, Japan and United Kingdom as developing market. By this integration level will be identified is the capital diversification done by Indonesian investor into international market still can provide opportunities for profit in the abnormal return or can reduce portfolio risk.

\section{Literature Review}

\subsection{Capital Market Integration}

Most study has been done on the issue of capital market integration. In this case, various indicators have been developed to measure the integration level. The general factor underlying this is the Law of One Price (LOOP), which is a fundamental principle of financial market integration. The law states that by not taking into account transaction and tax costs, the same securities shall also have the same price in all capital markets where such securities are traded. In other words, if there are two or more integrated capital markets, then the assets with identical cash flows should give the same returns in both markets. In the case of capital market integration, all assets that have the same risk and maturity characteristics have the potential to provide equal returns in different markets. In addition, in the absence of barriers that result in state and exchange rate premiums, financial assets with the same risk and liquidity are expected to achieve the same result, regardless of nationality or location (Von Furstenberg et al., 1989, Narayan et al., 2004; Marashdeh \& Shrestha, 2010).

\subsection{International Capital Diversification}

Based on portfolio theory developed by Markowitz's (1952), portfolio diversification has a useful purpose for investors; it can reduce portfolio risk because systematic risk on a single capital market can be a non-systematic risk to the global economy. This benefit will be felt by the investor if the international market being the target of diversification has a correlation or imperfect integration with the domestic market becoming the investor's home base. Chiou (2009) has investigated the benefits of international portfolio diversification for domestic investors in some countries which have findings: in the last 20 years the international market is increasingly integrated but along with the increase in capital market integration, the benefits of diversification are further down. The same is 
also found by Driessen and Leaven (2007) that the benefits gained by the diversification of the international portfolio is the form of reducing systematic risks declining along with the increasing integration of world capital markets. This benefit is felt for investors whose country has a high systematic risk because it performs an international portfolio with destination countries that have a low systematic risk. International investment opportunities are very attractive to investors who are looking for ways to minimize portfolio risk for given returns. It is a good fact that a low correlation between international equity markets provides a basis for reducing portfolio risk. However, the recent trend of correlation between equity markets has increased in general and, despite this increase, there is still evidence of significant diversification benefits both in developed markets and emerging markets. See Dimson et al. (2002), Goetzmann et al. (2005) and Li et al. (2003) for related findings. On the other hand, some authors find that the benefits of this diversification may actually be limited due to the strong long-term relationship between markets or even due to short sales constraints or transaction costs. See De Roon et al. (2001) and Syriopoulos (2004) for these related findings.

\subsection{Share Market Volatility Transmission}

The world economy due to capital liberalization which is emerged becomes the background of financial markets volatility transmission including the stock market. Volatility transmission basically sees how the effect of volatility and stock markets against the volatility of other stock markets. Price transmission is a condition in which prices in a market have the ability to affect other market prices, either spatially (geographically) or vertically (differences in the marketing chain) (Kartika, 2012). In the context of cross-country volatility transmission, the volatility of current domestic asset prices is the effect of domestic and foreign asset price volatility in the past (Engle \& Ng, 1993). Increased integration and interdependence of financial markets cause contagion effect between stock market that can cause influence of price volatility and return on a market to price volatility and other market return. The occurrence of volatility transmission is affected by the time difference between stock market transactions, where the stock market that has an earlier opening and closing time will affect the stock market whose opening time and closing are slower.

\section{Methodology and Procedure}

The type of data used in this study is secondary data in the form of daily time series data from January 1st, 2007 until April 30th, 2017. The data used in this study is the data of ASEAN + 5 stock price index of JKSE for Indonesia, KLSE For Malaysia, STI for Singapore, SET for Thailand, PSEi for Philippines, ASX for Australia, SSE for the People's Republic of China, Nikkei225 for Japan, KOSPI for the Republic of Korea, NSEI for India and stock price indices from 2 countries classified as developing markets i.e. NYSE for America and LSE for UK. The stock price index data of each country is transformed in the form of natural logarithmic (ln). The stock price index of each country is expressed in the form of local currency. The use of stock price indices in local currencies aims to restrict changes in visible only changes caused by stock price movements alone, avoiding the distortions imposed by depreciation in exchange rates.

There are several analytical methods used in this study. Selection of analysis method is determined based on the need to answer the purpose of this study, which are:

\section{1) Johansen Cointegration Test}

To identify the existence of integration among capital markets, analysis method used is Johansen cointegration test. In the cointegration test the thing to be observed is the Unrestricted Cointegration Rank Test (Trace) test. This test can be determined by looking at Trace Statistics and Critical Value (5\%). As indicator receives Null Hypothesis (Ho) or reject $\mathrm{H} 0$ (accept alternate hypothesis (H1)).

$\mathrm{Ho}=$ None, there is no cointegration relationship between variables

$\mathrm{Hi}=$ there is a cointegration relationship between variables in the model

The Trace test indicates each variable of the cointegrated model or in other words has a long run association.

\section{2) Dynamic Conditional Correlation (DCC-GARCH)}

This method is used to analyze the movement of short-term integration level between international capital market from year to year. The DCC approach calculates the correlation between variables as a function of the realization of past volatility (Bilio et al., 2016).

\section{3) Vector Error Correction Model (VECM)}

This method is used to answer the second goal of analyzing the volatility of the international capital market and its relationship with the integration of international capital markets that affect the advantages of international capital diversification in the opportunity to obtain abnormal return. In this VECM model, there is an Impulse Response 
Function (IRF) analysis to measure the effect of a price shock occurring in a certain country's market capital at a time to another price variable in the capital market of that other country at that time and in the future. In addition there is an analysis of Forecast Error Variance Decomposition (FEVD) which is useful to know exactly what countries have a big share in influencing fluctuations in certain countries (Firdaus, 2011).

\section{Findings and Discussion}

\subsection{Changes in Emerging Market Capital Market Policies Face Liberalization}

To support this research, Bekaert et al. (2000) have identified important times that affect financial liberalization and renewal processes occur in emerging market countries. Furthermore, to know the effect of foreign entering domestic market has been prepared on the beginning of liberalization by each country and the time of policy change after the opening of opportunities for foreigners to invest in the domestic market that can be seen in Table 1.

Table 1. Changes in emerging market capital market policies

\begin{tabular}{|c|c|c|}
\hline Country & Official Liberalization Date & Regulatory Changes \\
\hline Malaysia & Dec 1988 & $\begin{array}{l}\text { Budget calls for liberalization of foreign ownership policie to attract more foreign } \\
\text { investors. }\end{array}$ \\
\hline Philippines & Jun 1991 & $\begin{array}{l}\text { Foreign Investment Act is signed into law. The Act removes, over } 3 \text { years, all } \\
\text { restrictions on foreign investments. }\end{array}$ \\
\hline Thailand & Sep 1987 & $\begin{array}{l}\text { Inauguration of the Allen Board on Thailand's Stock Exchange. The Allen Board } \\
\text { allows foreigners to trade stocks of those companies which have reached their foreign } \\
\text { investment limits. }\end{array}$ \\
\hline Indonesia & Sep 1989 & $\begin{array}{l}\text { Minister of finance allows foreigners to purchase up to } 49 \% \text { of all companies listing } \\
\text { shares on the domestic exchange excluding financial firms. }\end{array}$ \\
\hline Korea & Jan 1992 & $\begin{array}{l}\text { Partial opening of the stock market to foreigners. Foreigners can now own up to } 10 \% \\
\text { of domestically listed firms. } 565 \text { foreign investors registered with the Securities } \\
\text { Supervisory Board. }\end{array}$ \\
\hline Taiwan & Jan 1991 & $\begin{array}{l}\text { Implementation date of phase two of liberalization plan. Eligible foreign institutional } \\
\text { investors may now invest directly in Taiwan securities subject to approval. }\end{array}$ \\
\hline China & Dec 2002 & $\begin{array}{l}\text { Allows foreign investors to buy and sell yuan-denominated shares in China's } \\
\text { mainland stock exchanges }\end{array}$ \\
\hline
\end{tabular}

Table 1 explains that liberalization acts were formally grouped in the late 1980s or early 1990s. The policy changes in response to liberalization began with the removal of barriers to foreign capital inflows to the domestic market. These policy reforms cover various aspects of macroeconomics, finance and politics.

\subsection{Indonesian Capital Market Integration Analysis with Developing and Emerging Market}

\subsubsection{Johansen Cointegration Test}

To analyze the existence of capital market integration between 12 countries Johansen Cointegration test is conducted. This test does not provide information on integration level between the capital markets but only informs that on a certain model system there is an integration. The results of the Johansen Cointegration test are shown in Table 2.

Table 2. Findings on Johansen cointegration test

\begin{tabular}{ccccc}
\hline $\begin{array}{c}\text { Hypothesized } \\
\text { No. of CE(s) }\end{array}$ & Eigenvalue & $\begin{array}{c}\text { Trace } \\
\text { Statistic }\end{array}$ & $\begin{array}{c}0.05 \\
\text { Critical Value }\end{array}$ & Prob.** \\
\hline None ${ }^{*}$ & 0.568279 & 394.1113 & 348.9784 & 0.0003 \\
At most 1 & 0.395723 & 291.6341 & 298.1594 & 0.0887 \\
At most 2 & 0.335339 & 230.1799 & 251.2650 & 0.2819 \\
At most 3 & 0.295273 & 180.3456 & 208.4374 & 0.4772 \\
At most 4 & 0.246728 & 137.6524 & 169.5991 & 0.6529 \\
At most 5 & 0.179932 & 103.0863 & 134.6780 & 0.7435 \\
At most 6 & 0.161706 & 78.88533 & 103.8473 & 0.6581 \\
\hline
\end{tabular}

Note. Trace test indicates 1 cointegrating eqn(s) at the 0.05 level.

* denotes rejection of the hypothesis at the 0.05 level; **MacKinnon-Haug-Michelis (1999) p-values. 
Based on Table 2, it can be seen that confidence level at $95 \%$ is found 1 cointegration among 12 indices. This provides information that there is price integration among stock indices of 12 Countries. To see which capital markets of any country have a significant long-term relationship with Indonesian capital market is through the estimation of VECM model presented in Table 3.

Table 3. Findings on VECM estimated model between Indonesia and 11 countries

\begin{tabular}{lcclcc}
\hline Variable (DM) & t-statistics & Coefficient & Variable (EM) & t-statistics & Coefficient \\
\hline US $(-1)^{* *}$ & 7.23 & 41.71 & Korea $(-1)^{* *}$ & -7.26 & -32.44 \\
Japan $(-1)^{* *}$ & -2.74 & -13.61 & China $(-1)^{* *}$ & 8.69 & 26.08 \\
Singapore $(-1)^{* *}$ & 6.74 & 50.58 & Malaysia (-1) & 0.91 & 3.72 \\
UK $(-1)^{* *}$ & 7.01 & 87.06 & Philppina (-1) & -1.38 & -4.15 \\
Australia (-1)** & -10.61 & -124.21 & Thailand (-1)** & -4.91 & -17.53 \\
& & & Taiwan $(-1)^{* *}$ & -2.21 & -12.57 \\
\hline
\end{tabular}

Note. asterisk sign $(* *)$ stated significant variable on $\alpha=5 \%$.

Table 3 provides information that almost all countries provide long-term relationships with Indonesia, only the capital markets of Malaysia and the Philippines which are insignificant. This may be due to the policies of the Malaysian and Philippine governments that reduce the time period of investment resulting in a barrier to entry for foreign investors who want to do long-term investation as they prioritize local investors.

\subsubsection{Integration Level Measurement by DCC GARCH}

The return variance correlation between Indonesian stock market and 6 other countries stock markets are categorized as emerging market countries that can be seen in Figure 2. This correlation can be used as a short-term information for investors in the analysis of integration level so that the investors can choose another countries' stock market as the diversification purpose well. The development of Indonesian capital market integration with other countries' capital markets tends to stagnate in the period of 2007-2017. But in a certain period there is a significant change of integration level which took place in 2008 and 2015. In 2008 it was known that there was a global financial crisis began with the America Shutdown tragedy so that it was impacted to the whole country. As in 2015 one of the occasions happened was the financial crisis that occurred in Europe. Some countries joined in the European Union were crisis and close to pailit because its foreign debt is greater than its GDP as experienced by Greece.

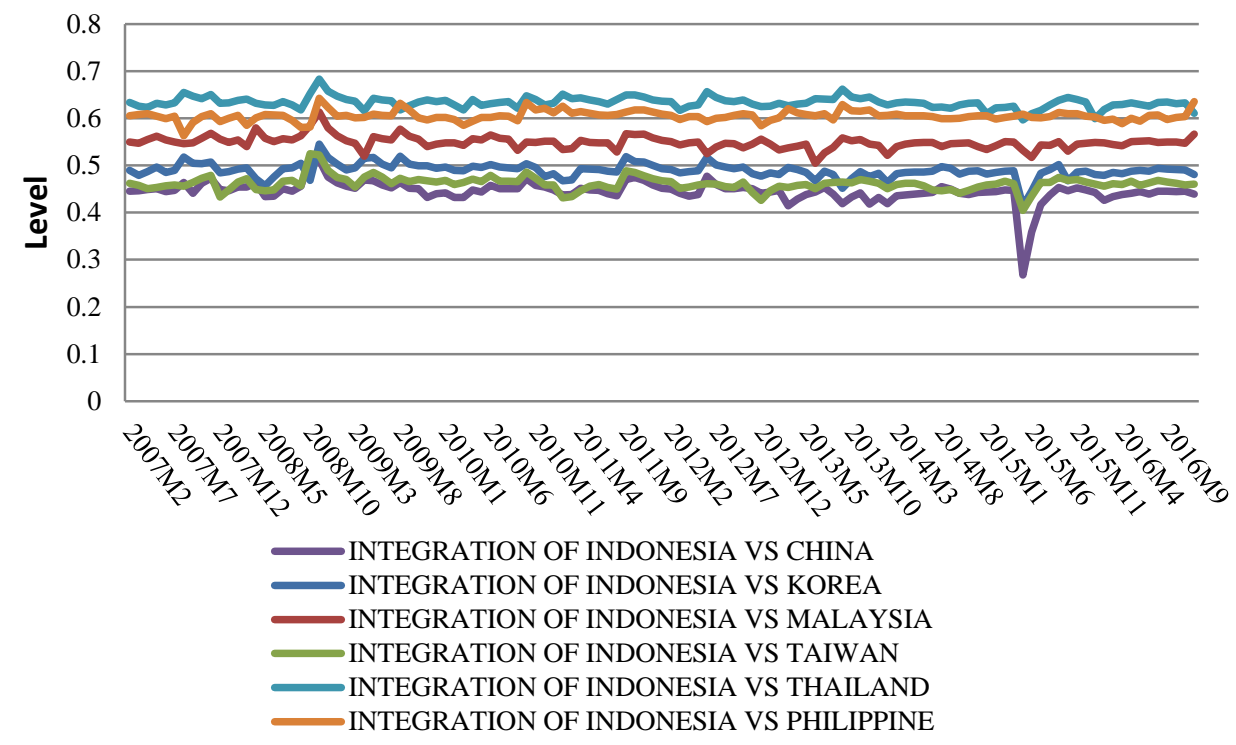

Figure 2. Indonesian integration level with emerging market

The impact on Indonesian integration compared to another countries has a different respond. In 2008, integration level is strengthened between 12 international stock markets while crisis tragedy in 2015 weakened the 
integration level significantly except for integration between Indonesia and ASEAN stock markets such as Malaysia, Thailand and the Philippines.

According to Figure 2 and 3 degrees the strongest integration of Indonesian stock market is along with Thai stock market in the range of 0.63 while the weakest is the integration of Indonesian stock market with Japanese stock market in the range of 0.35 . From this information, it can be concluded that the strongest integration of Indonesian stock market along with ASEAN stock market, because most of the ASEAN stock market is categorized as emerging market, Singapore is the only ASEAN country considered as developing market.

Indonesian stock market has a weak integration level, the developing country such as United States has integration level of 0.46, Britain at 0.5, Australia at 0.51 and Japan at 0.35 . This shows that the diversification of capital from the perspective of Indonesian investors still provides benefits if the diversification of capital is aimed at countries that have different developmental stage and region.

The existence of ASEAN economic community cooperation agreement makes some ASEAN member countries change their respective capital market policy. The new policy makes the capital market more open to foreign investors. In terms of establishing companies and ownership, Thailand increased the ownership of foreign securities companies by up to $100 \%$ from only $49 \%$ of paid-in capital. Thailand grants the ownership permit up to $100 \%$ paid up capital with the condition that after 5 years at least $50 \%$ of paid up capital must be owned by a financial institution established under applicable specific Thailand law. As for Malaysia foreign ownership in the securities company is permitted to a maximum of $70 \%$ from the previous $30 \%$. The Philippines also reduced the restrictions on foreign ownership in investment banks from $49 \%$ to $51 \%$ (Setiawan, 2012).

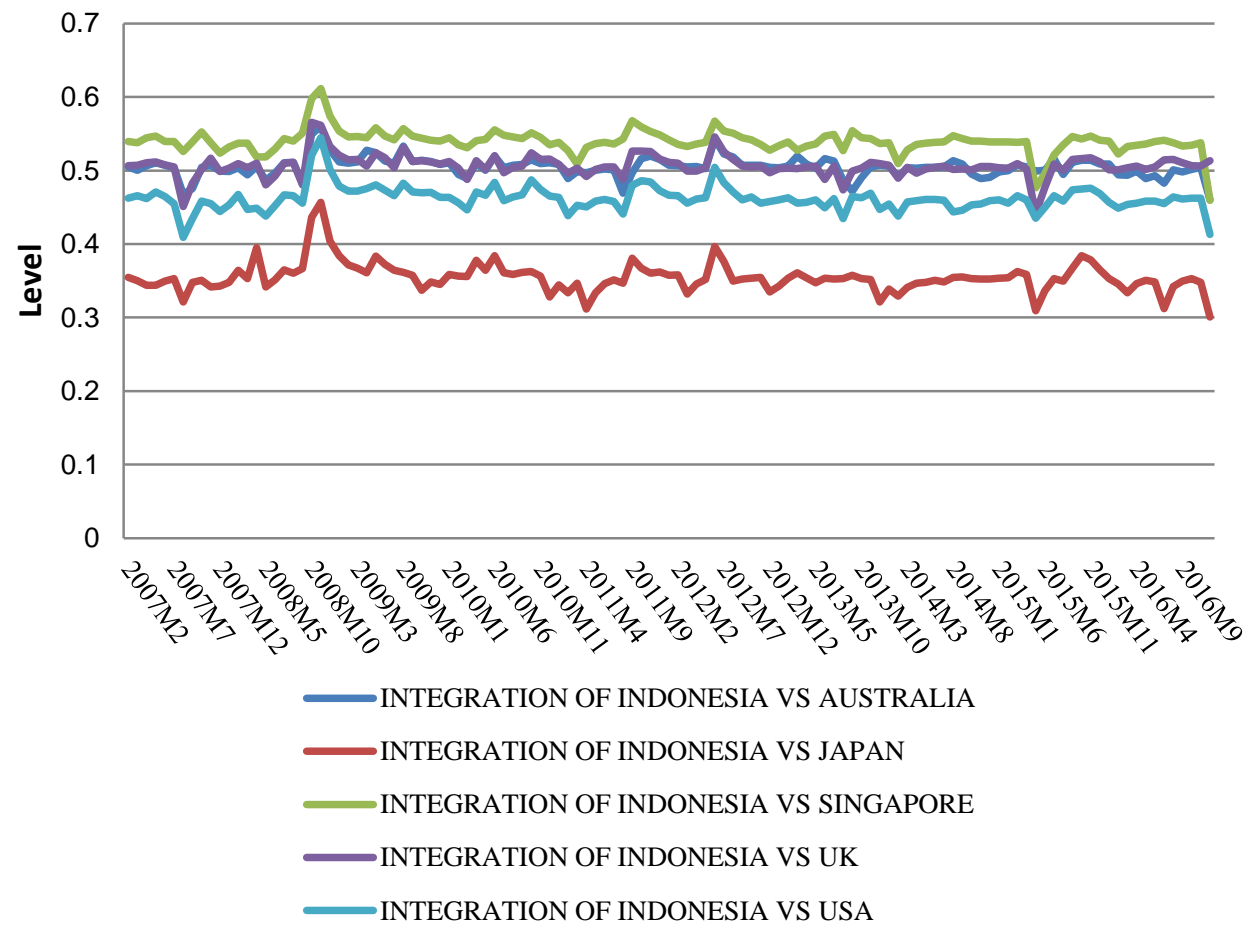

Figure 3. Indonesian integration level with developed market

Policy changes also occurs in aspects of business activity. Singapore loosen its commitment by removing the policy of not allowing new stock exchange members from foreigners. Indonesia has eased labor regulations, foreign workers previously only permitted for director level, recently also for managers and experts/consultants (transfers within the company). The policy changes that make ASEAN capital markets more integrated can be less favorable to Indonesian investors who want to reduce risk with ASEAN capital portfolio.

\subsection{The Relationship between Volatility and Integration of International Capital Market}

\subsubsection{Impuls Response Function (IRF) Analysis}

To know the impact of International stock index price shock towards Indonesian stock price index, then Impulse Response Function is applied. IRF tracks the effects of one of the shocks to other shocks in the present and 
future of endogenous variables. A shock in the i-endogenic variable will directly affect the variable itself and will spread to other endogenous variables through the dynamic VAR structure. IRF gives direction the relationship of magnitude influence between endogenous variables. Thus the shock of a variable in the presence of new information will affect the variable itself and other variables in the VAR system.

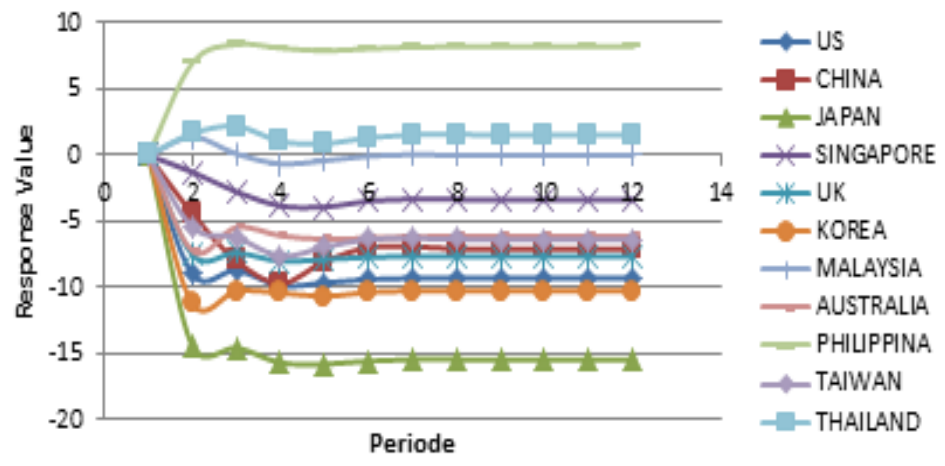

Figure 4. Indonesian stock market respond towards another variable shock

Figure 4 shows that if a shock happened to Indonesian capital market, it will impact the capital markets of other countries, the response is different from each market, the respond of Philippines, Thailand and Singapore are positive and other markets respond negatively. The impact of shock is only felt until the period of the 2nd month and back to the balance condition. Based on these results, the volatility that occurred in Indonesia still provides an opportunity for Indonesian investors to get abnormal return from international diversification. Opportunities can be taken if diversification is addressed to countries that have negative responses such as Singapore, America, China, and Japan.

\subsubsection{Forecast Error Variance Decomposition (FEVD) Analysis}

From FEVD analysis it can be seen the percentage of variation in an endogenous variable which is explained by any disturbance present in the applied VAR model. In other words, FEVD analysis is used to find out which variable is the most important in explaining the change of a variable. The table shows the percentage of variation of each fundamental endogenous variable by the shock of other variable shocks. From the FEVD results, it can be concluded that the variation of more variables is determined by the variable itself.
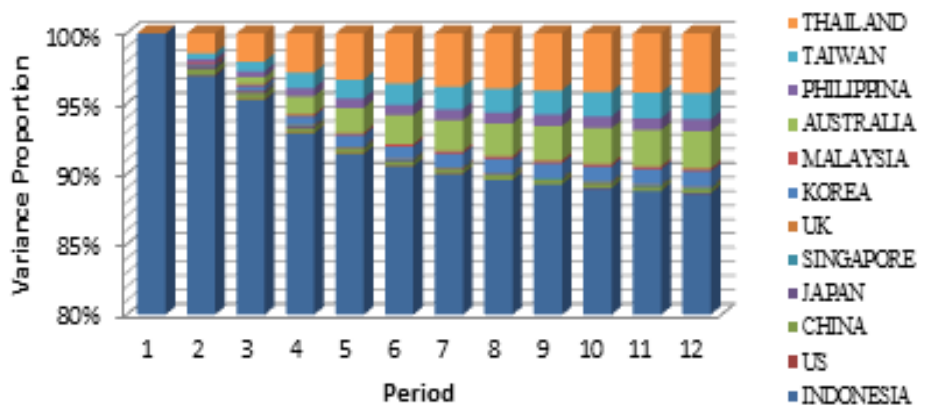

Figure 2. Variance decomposition JKSE

Figure 5 shows that when shock occurs from other markets, the proportion of variance in Indonesian stock market is largely influenced by the Indonesian stock market (JKSE) itself, Thailand stock market (SET), and Australian stock market (ASX), while other variables indicate small proportions. At the beginning of the period, the JKSE variance is determined by JKSE itself at $100 \%$, then in the subsequent period determined by other stock markets whose contribution has not significantly affected the volatility of the Indonesian capital market until the 12th period has returned to equilibrium.

Based on the findings of previous studies, integration of international capital markets must be addressed critically by Indonesian investors who will do international diversification. Thus the implications that can be given to Indonesia government and Indonesian investor as follows: 


\section{1) Indonesian Investor}

In international diversification, the portfolio manager should consider the destination country of diversification so that in accordance with this research, investors should diversify their capital to the country with the characteristics of the developing market. The investment between countries can reduce or avoid losses due to systematic risk caused by internal factors of Indonesia own.

\section{2) Government/Authority}

For the government, this research can be a consideration to provide policy on investment or trade activities between countries. The findings of this study indicate that JKSE has a long-term relationship with the NYSE and STI, therefore Indonesian government can determine future plans to make preventive efforts in case of shock coming from the NYSE or STI by attracting many local investors to invest in Indonesian capital market JCI is expected to have a fairly strong stability.

Several policy implications are also drawn on the basis of the research findings. First, it should be pointed out that financial regionalisation will, through promoting the monitoring of government behaviour by participants in regionalised financial markets, provide the government with discipline for macroeconomic policy management and, hence contribute to stability of the financial system. Second, policy makers in the ASEAN countries are interested in identifying the degree of integration of financial markets as part of negotiating and defining an agenda of reform and liberalisation in the region. Third, the considerably high regional cooperation and integration may provide the ASEAN a stronger voice in global forums and greater influence on global policy making. Cuong (2007) argues that greater regional policy dialogue and cooperation are important because they provide the region with influence over global rules setting.

\section{Conclusion and Suggestion}

\subsection{Conclusion}

Based on the findings of research and data analysis that has been done, it can be concluded that during the period of research that is 2007-2017, there is an integration or long-term relationship between Indonesia capital market JKSE with international capital markets 11 countries. However none of the countries are perfectly integrated with Indonesia so that Indonesian investors can still get a beneficial opportunity in international diversification especially if Indonesian investors diversify their capital portofolio to developed markets which give more risk reduction than to emerging markets.

\subsection{Suggestion}

Suggestions in this study refers to the limitations of data that can be accessed, therefore suggestions for further research include: (1) The next researcher can formulate the optimal portfolio that can be informed to Indonesian investors and (2) The next research is expected to analyze influence of dummy before and after global crisis towards international capital market integration.

\section{References}

Bekaert, G., Harvey, C. R., \& Lumsdaine, R. (2002). Dating the integration of world capital markets. Journal of Financial Economics, 65, 203-247. http://dx.doi.org/10.1016/S0304-405X(02)00139-3

Bilio, M., Donadelli, M., Paradiso, A., \& Riedel, M. (2016). Which market integration measure. Journal of Banking and Financ, 76(3), 150-174. https://doi.org/10.2139/ssrn.2883995

Chiou, W. P. (2009). Benefits of international diversification with investment constraints: An over-time perspective. Journal of Multinational Financial Management, 19(2), 93-110. https://doi.org/10.1016/j.mulfin.2008.08.001

Cuong, T. H. (2007). Financial integration and dynamic linkage in the ASEAN-5. [dissertation]. Bangor (UK): Bangor Business School.

De Roon, F. A., Nijman, T. E., \& Werker, B. J. M. (2001). Testing for mean-variance spanning with short sales constraints and transaction costs: The case of emerging markets. Journal of Finance, 56, 721-742. https://doi.org/10.1111/0022-1082.00343

Dimson, E., Marsh, P., \& Staunton, M. (2002). Triumph of the Optimists: 101 Years of Global Investment Return. New Jersey (USA): Princeton University Press.

Driessen, J., \& Laeven, L. (2007). International portfolio diversification benefits: Cross-country evidence from a local perspective. Journal of Banking \& Finance, 31(6), 1693-1712. https://doi.org/10.1016/j.jbankfin.2006.11.006 
Dunis, C. L., \& Shannon, G. (2005). Emerging markets of south-east and central Asia: Do they still offer a diversification benefit? Journal of Asset Management, 6(3), 168-190. http://dx.doi.org/10.1057/palgrave.jam.2240174

Engle, R. F., \& Vk, Ng. (1993). Measuring and testing the impact of news on volatility. The Journal of Finance, 5, 1749-1778. http://dx.doi.org/10.1111/j.1540-6261.1993.tb05127.x

Fan, K., Lu, Z., \& Wang, S. (2009). Dynamic linkages between the China and international stock markets. Asia-Pacific Financial Markets, 16(3), 211-230. http://dx.doi.org/10.1007/s10690-009-9093-5

Firdaus, M. (2011). Aplikasi Ekonometrika untuk Data Panel dan Time Series. Bogor (ID): IPB Press.

Goetzmann, W. N., Li, L., \& Rouwenhorst, K. G. (2005). Long term global market correlations. Journal of Business, 78, 1-38. Retrieved from http://ssrn.com/abstract=288421

Jiang, C., Ma, Y., \& An, Y. (2013). International diversification benefits: An investigation from the perspective of Chinese investors. China Finance Review International, 3(3), 225-249. http://dx.doi.org/10.1108/CFRI-06-2012-0071

Kartika, T. R., Achsani, N. A., Manurung, A. H., \& Nuryartono, N. (2012). Transmission of stock return volatility in Indonesia (IHSG) towards USA (DJIA), Hongkong (HSII) and Singapore (STI). Finance and Banking Journal, 14, 16-29. Retrieved from http://perbanas.id/jurnal/index.php/jkp/article/download/166/55

Li, K., Sarkar, A., \& Wang, Z. (2003). Diversification benefits of emerging markets subject to portfolio constraints. Journal of Empirical Finance, 10, 57-80. https://doi.org/10.1016/S0927-5398(02)00027-0

Marashde, H., \& Shrestha, M. N. (2010). Stock Market Integration in the GCC Countries. International Research Journal of Finance and Economics, 37(37), 102-114. Retrieved from http://www.internationalresearchjournaloffinanceandeconomics.com/ISSUES/IRJFE\%20issue\%2037.htm

Markowitz, H. (1952). Portfolio selection. Journal of Finance, 7, 77-91. http://dx.doi.org/10.111/j.1540-6261.1952.tb01525.x

Setiawan, S. (2012). Analisis sektor pasar modal Indonesia menghadapi liberalisasi dan integrasi ASEAN. Policy $\begin{array}{lllll}\text { Paper } & \text { Kebijakan } & \text { Fiskal, } & 2 . & \text { Retrieved }\end{array}$ https://www.kemenkeu.go.id/Kajian/analisis-sektor-pasar-modal-indonesia-menghadapi-liberalisasi-dan-int egrasi-asean

Syriopoulos, T. (2004). International portfolio diversification to Central European stock markets. Applied Financial Economics, 14, 1253-1268. http://dx.doi.org/10.1080/0960310042000280465

Von Furstenberg, G. M., Jeon, B. N., Mankiw, N.G., \& Shiller, R. J. (1989). International stock price movements: Links and messages. Brookings Papers on Economic Activity, (1), 125-179. http://dx.doi.org/10.2307/2534497

\section{Copyrights}

Copyright for this article is retained by the author(s), with first publication rights granted to the journal.

This is an open-access article distributed under the terms and conditions of the Creative Commons Attribution license (http://creativecommons.org/licenses/by/4.0/). 